\title{
correspondence
}

\section{In support of a boycott}

SIR,-We read with great interest the letter by Richard Peto and Richard Doll (1 December, page 384) concerning the congress of the International Union Against Cancer which is scheduled to take place in Buenos Aires, Argentina October 1978 and the advisability of conducting a boycott in view of the violations of human rights in that country. It is stated that "advice and comments from other scientists, especially those who, unlike ourselves, have worked under repressive regimes, would be timely, both about the general advisability or inadvisability of such boycotts" in a country where there is conclusive evidence of widespread repression, torture and systematic violations of human rights.

The Association Solidarité Franco Argentine (a non-profit making, humanitarian organisation based in France) has contacted many Argentinian scientists regarding this problem. Although they asked not to be identified by name for fear of the consequences to their families still living in Argentina, the general opinion is that whatever measures are taken to show concern for the fate of the many scientists that have simply "disappeared" at the hands of the military government, there is one thing which should not be permitted: that the Argentinian government should use the success of the congress to claim to the world that the scientific community condones its present policies, by being present at the meeting and keeping silent about the plight of Argentinian scientists.

Unfortunately this is what seems to be happening in Argentina right now. A recent article from the strictly censored local press says that in spite of the efforts of some scientists, who pretend to be motivated for humanitarian reasons but in fact echo slogans of international terrorism, the congress will be a success. To prove this, the article mentions that only 500 participants had registered for the previous Florence meeting, compared to the 3,000 for the Buenos Aires event. Dr Humberto Veronessi, President of the International Union Against Cancer, is quoted as having said "I believe that to choose Buenos Aires for this meeting is one of the most intelligent actions taken by the Union". This type of article suggests that the Argentinian generals have already invested high hopes in a "business as usual" congress as a measure of international acquiescence.

Among the many well known scientists to have publicly protested against the terrorising policies of the military Junta are Nobel prize winners Louis Néel, Alfred Kastler, Tsung Dao Lee and Hans Bethe (New York Times, 27 November, 1977). Concerned scientists attending the Buenos Aires meeting can take similar action by openly voicing their concern about the many Argentinian scientists who have vanished. This could be done by organising a petition to be read at the meeting or a press conference to be held in the presence of foreign journalists.

What has happened to Drs Federico Alvarez Rojas, Antonio Misetich, Gabriela Carabeli, Eduardo Pasquini, Julia Huarque, Federico Ludden, Manuel Tarchitsky and Juan Carlos Gallardo, all of them physicists, and the many others kidnapped, in many cases, with their families? Why aren't the numerous concentration camps open to Red Cross personnel? There is every reason to suspect that the worst is happening, just as it did in Nazi Germany, where similar questions puzzled many scientists, and massacres were taking place not far from the place where scientific meetings were being held.

Exiled Argentinian scientists beg the rest of the scientific community to stand up, whether by boycotts or in other ways. "Anti-science" sentiments will certainly not be aggravated by a public stance against torture and death. Many lives may instead be spared. Yours faithfully,

\section{Association Solidarité} GuY TASSAR'T

Franco Argentine,

Grenoble, France

\section{Soft energy paths}

SiR,--Peter Chapman is right to say (10 November, page 128 ) that my US calculations in Soft Energy Paths: Toward a Durable Peace should be redone for the UK-as several colleagues are now attempting. But in suggesting how my US numbers "fail on a num- ber of technical issues" he may mislead UK readers unfamiliar with transatlantic differences.

First, he says my 0.55 capacity factor for US pressurised-water reactors (PWRs) is "unrealistically low", "absurd", and "silly", and so it must seem to people used to British gascooled reactors which are far more reliable (though allegedly more costly). Yet my citations show that the US empirical average through 1976 is 0.61 (0.59 for all light-water reactors) and falling as less reliable larger plants come on line; that the officially projected lifetime average is 0.57 ; and that the 10-year levelised average expected for new big PWRs on the basis of exhaustive statistical analysis of existing units is 0.49 . Thus my assumed 0.55 is arguable either way but hardly out of court under US conditions. (European units tend to do better, Japanese ones worse.)

Second, in my analogy suggesting that if we could mass-produce power stations the way we do cars they would cost an order of magnitude less than they do, but we can't because they're too big, I did take account of generator cost and of equivalent engine lifetime. (I also noted many important economies of small scale-related to reliability, reserve margin, short lead times, etc-which are not "very dubious" nor even empirically controversial. For a taxonomy of scale issues, see my "Soft Energy Technologies" in the 1978 Annual Review of Energy.)

Third, the $\$ 100 /\left(\mathrm{m}^{2}+\mathrm{m}^{3}\right)$ solar installed price Dr Chapman quotes is for the mid-1980s (in 1976 dollars), not now: my late-1970s estimate of $\$ 150$ is broadly consistent with his. My $\mathrm{Ca} 1985$ price estimate is based on empirical prices now obtainable by careful shopping in a fairly mature solar market (such as California, with due adjustments for different climatic needs). Current UK prices in an infant market with little volume or diversity are understandably higher but do not indicate what could be achieved. I do not see why the "cost of storage in the UK" should be $£ 300 / \mathrm{m}^{3}$ or even $£ 40 / \mathrm{m}^{3}$, as I cited empirical installed US prices, for modular underground tanks of tongue-and-groove concrete slabs, equivalent to $£ 12-20 / \mathrm{m}^{3}$ for sizes of order $10-10^{2} \mathrm{~m}^{3}$, and several even cheaper methods are available. Perhaps they are 
not in use in the UK, but that is not my fault. Further, solar heat's marginal-cost advantage is not fragile but robust: even with collectors costing twice Dr Chapman's assumed $£ 50 / \mathrm{m}^{2}$, neighbourhood-scale seasonal-storage solar space heating in the UK should compete with any long-run marginal source and probably with OPEC oil too (see the Ann. Rev. En. article).

Fourth, my analysis assumed neither large wind machines nor growing special biomass crops (rather, it assumed the conversion of present farm and forestry residues requiring no additional land); and I did not ignore, but repeatedly emphasised, the economic argument for matching energy quality to end-use needs. One of the reasons for persistent official commitments to a hard energy path is the prevalence of asymmetric cost comparisons: governments compare the costs of various types of big power stations and synthetic-fuel plants with each other, then compare the costs of soft technologies not with their hard-technology competitors but with the historically cheap fossil fuels that all are meant to replace. This makes some soft technologies fail a test which hard ones would fail by a far wider margin. So long as such chicanery goes unremarked, economically and politically disastrous energy policies will continue to prevail over common sense.

Yours faithfully, AMORY B. Lovins

Friends of the Earth,

London, UK

\section{Gene inquiry is timely}

SIR,-Your editorial (8 December, page 461) criticised the decision of the House of Commons Select Committee on Science and Technology to set up a subcommittee on genetic engineering. It did so in remarkably complacent terms which seem to us to pass all too lightly over the problems which remain unexamined and unresolved in this area and to exaggerate the extent to which public debate has occurred. In our view it is not true to say there has been exhaustive scrutiny or debate in the UK of the issues involved. The "general feeling" of scientists involved in the field may be that the hazards have been overplayed, but this attitude ignores other issues which concern the public.

Many of the hazards involved in genetic engineering require much wider examination. The analysis so far has been far from comprehensive, and the actions taken incomplete. For example, recommendations made by the Ashby Committee three years ago, such as the institution of epidemiological surveys of workers in communities where these experiments are undertaken, have not yet been implemented. And the body established to regulate work in this field (the Genetic Manipulation Advisory Group) has few powers, relies on voluntary cooperation and is already experiencing problems in dealing with confidentiality of industrial information.

The examination of this area by the select committee could achieve much. It could help bring about a much wider appreciation of the far-reaching issues involved. It could also provide a valuable independent assessment of the policy-making procedures being created in this area which are currently screened from the public gaze by the protection of the Official Secrets Act. Now is the time for such an examination, before the problems of industrial exploitation are upon us. This is an urgent matter which requires as thorough an analysis as that at last being given to nuclear power.

We applaud the initiative taken by the select committee and feel sure that it will take the opportunity to take note of the wide range of views on this topic.

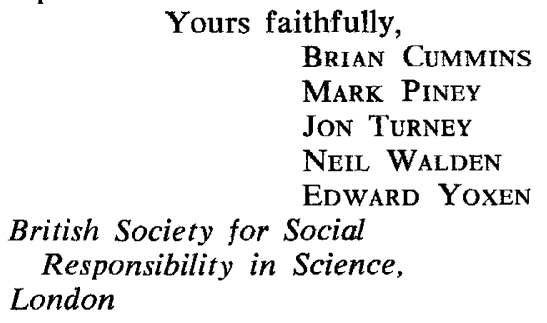

\section{What happened at Heimaey?}

SIR,--In his search for a deontological code for volcanology, Haroun Tazieff (8 September, page 96) has elected not to practise his own preaching and indeed based some of his own arguments "on deliberately false data". We are astounded by his inclusion of the waterchilling of the Heimaey lava in 1973 in his tabulation of erroneous volcanological diagnoses, and his account of countermeasures taken by Icelanders as defence against lava flows on Heimaey indicate either lack of familiarity with relevant literature or wrong interpretation of actual facts.

In an attempt to prevent westward advance of the Heimaey lava over the town and towards the harbour, earth dams were bulldozed in late January and early February 1973. Experiments with chilling of lava-fronts by waterpumping started on 6 February and while lava advance could not be prevented, local slowing-down and diversion was achieved. Thus chilling of lava in this way is believed to have saved electric power-line installations for a while and diverted lava from the harbour wall on
6 March. Subsequently, pumps with total capacity of 1,000 litres per sec were employed, feeding a network of $20 \mathrm{~cm}$ diameter flexible plastic tubing system from the harbour to the lava fronts which were threatening further destruction of the town. This large-scale operation resulted in doubling of height of some lava fronts (Th. Einarsson, The Heimaey Eruption, Heimskringla, Reykjavik (1974)) as production of clinker and blocky rubble was increased on the lava surface. This increasing clinker accumulation rate seems to have decelerated or halted advance of the lava in certain areas.

Our knowledge of the mechanics of lava movement is still rudimentary. Recent theories, such as that of Hulme (Geophys. Journ. Roy. Astr. Soc. (1974)), make it clear that the strength of the flow front and channel levees are of great importance in controlling lava shape. As lava levees or flow fronts are made stronger and thicker, lava builds up behind these natural barriers. Lava will clearly attempt to break out or advance at the weakest front. By preferentially strengthening a levee or flow front by such a technique as watercooling it seems probable that the lava will prefer to advance elsewhere. Levees or flow fronts are only minor parts of the total lava at any time, but increase in the strength of these areas may be highly effective in diverting lava. By choosing a strategic zone such as a levee, cooling need only be concentrated on a small part of the flow. Evidence from the Heimaey experiment suggests that the uncooled flow front ranged $10 \mathrm{~m}$ to $15 \mathrm{~m}$ in height, whereas the flow front treated by water pumping ranged from $20 \mathrm{~m}$ to $30 \mathrm{~m}$ and possibly as much as $40 \mathrm{~m}$.

Finally there is a requirement to substantially improve our understanding of lava flow mechanisms. This is an area of research that illustrates the importance of volcanology turning from a qualitative to a quantitative science. In this way some of the noticeable subjectivity in judging volcanic phenomena, which is amply illustrated in Dr Tazieff's note, can be replaced by informed opinion, based on detailed understanding of the physics and chemistry of volcanic processes.

The determination of the people in Heimaey in fighting the advancing lava was not daunted by defeatist utterances of some sceptics at the time of the eruption. We hope that readers of the otherwise useful note by Haroun Tazieff will likewise dismiss his pessimism about the usefulness of watercooling in diverting lava flows.

Yours faithfully,

HaRaldur Sigurdsson

STEPHEN SParks

University of Rhode Island,

Kingston, USA 